FACTA UNIVERSITATIS

Series: Mechanical Engineering Vol. 17, N 3, 2019, pp. 321 - 332

https://doi.org/10.22190/FUME180110005B

Original scientific paper

\title{
ADVANCED MORPHOLOGICAL APPROACH IN AEROSPACE DESIGN DURING CONCEPTUAL STAGE
}

\author{
Andreas Bardenhagen ${ }^{1}$, Dmitry Rakov ${ }^{2}$ \\ ${ }^{1}$ Aircraft Design and Aerostructures at the Institute of Aeronautics and Astronautics, \\ Technische Universität Berlin, Germany \\ ${ }^{2}$ A. A. Blagonravov Mechanical Engineering Institute, \\ Russian Academy of Sciences, Russia
}

\begin{abstract}
This paper presents an advanced morphological approach supporting designers and developers in their search for as well as synthesis and analysis of new engineering solutions during the conceptual design stage. The proposed method is based on the cluster analysis and the set theory, the set of rules and engineering implementations maximizing the gain of the products potential. The number of possible combinations using the standard morphological technology is extremely large. We present a mathematical framework that handles this problem. The method was evaluated with case studies of new engineering solutions in aerospace, ecology and adaptive soundproofing system. The case studies verified the significant potential of the proposed approach in comparison with the methods presently in use.
\end{abstract}

Key Words: Conceptual Design Support, Solution Space, Morphological Matrix, Design Modeling, New Engineering Solutions, Unmanned Aircraft Systems (UAS)

\section{INTRODUCTION}

In engineering practice it is usual to strive for a new optimum engineering solution (ES) within the constraints directly at the beginning of the project. The search for a new ES makes it necessary to start with the main tasks of the system analysis, namely, decomposition, analysis and synthesis of an ES. An analysis is carried out to determine the properties of the ES and its operation, while the synthesis task consists in the development of an ES model, the definition of its structure (structural synthesis) and the

Received January 30, 2018 / Accepted December 21, 2018

Corresponding author: Rakov Dmitry

Affiliation, address: Mechanical Engineering Institute, 101990 Moscow, M.Harinonevsky per, 4. Russia

E-mail: rdl@mail.ru 
corresponding parameters (parametric synthesis or parametric optimization) which are necessary for an efficient functioning of the ES and the achievement of the stated goal.

The structure represents the most concrete way of representing a system, and the most concrete stage in generating systems during the conceptual stage of design process $[1,2]$. Polovinkin has examined three conceptual design levels of an ES [3]. The characteristics of the synthesized systems on the third level of an optimization can be improved (statistically) in average by $10-15 \%$ (Fig. 1). At levels 1 and 2 the characteristics can be improved in average by $30-35 \%$ and sometimes more.

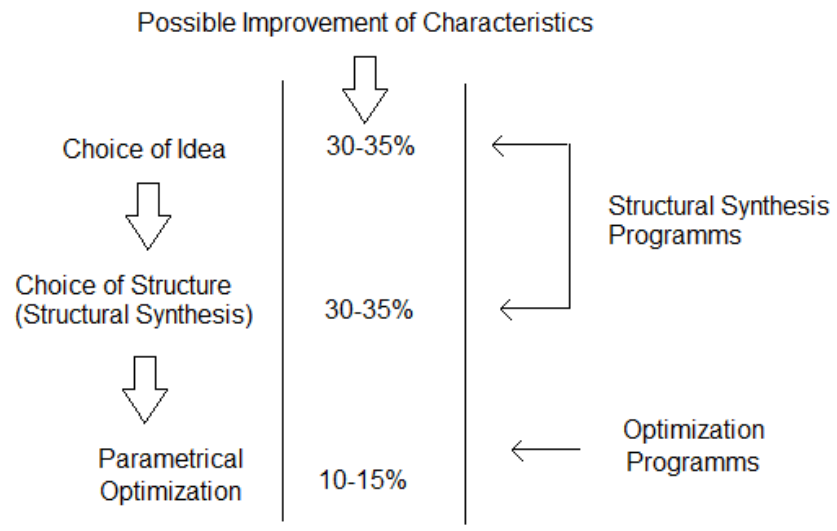

Fig. 1 Improving system performance depending on conceptual design levels

The ES structure is composed of a set of elements (constructive, functional or technological) and a set of their relationships. The search of the rational structure of an ES is the attainment of compromise levels for a number of criteria. The target function for optimum search does not correspond to the main requirements of the theoretical method for optimization because it is discontinuous or cannot always be determined; it exists in operator notation; it is not based on analytical expressions; it is not differentiable, nor unimodal; neither is it separable nor additive. It is impossible to build a hyper surface of the target function and to predict its change on an increment of variables [4].

During the stage of structural synthesis of a new ES intuitive (Brainstorming, Mind Mapping, TRIZ, Synectics etc.) and discursive (morphological analysis, cause-and-effect diagram, Osborn-Checklists, etc.) techniques can be used. The most common method among the discursive techniques is a morphological analysis (MA).

The Morphology Analysis was developed by Fritz Zwicky - a Swiss astrophysicist based at the California Institute of Technology (Caltech) [5]. Researchers applied the morphological analysis first to astronomical studies and the development of rocket propulsion systems. As a problem-structuring and problem-solving technique, the MA was designed for multi-dimensional and non-quantifiable problems where causal modeling and simulation do not function well, or not at all [6].

The morphological design will be structured into a set of functional and characteristic attributes [7]. Against each of these attributes, the designer will have to select a 
conceptual solution. The combination of all these solutions then generates the final design concept [8].

The MA has been applied by a number of researchers in the fields of engineering science $[9,10]$. This is considered as the Hierarchical Morphological Multicritieria Design providing conceptual lens. This approach is based on ordinal estimates of design alternatives for system parts/components, and on new interval multiset estimates for design alternatives with special attention to the aggregation of modular solutions [11].

The morphological approach is widely used in Germany. The Society of German Engineers has developed two sets of rules for engineers: VDI 2222, "Design methods: methodical development of engineering principles" [12] and VDI 2221, "Design methods of technical systems and products" [13], in which it is recommended to use the morphological approaches to find a new ES.

The disadvantage of morphological methods is the impossibility to analyze all possible variants - potentially the number of generated variants in the morphological array can be enormous (up to a hundred thousand and millions possible variants).

\section{MethodOLOGICAL BACKGROUND}

To reduce the dimensionality of a morphological array an advanced morphological approach is developed. Applying the means of this approach makes it possible to solve two groups of tasks:

- Direct task: After creating a morphological array the search for engineering solutions occurs with the help of clustering.

- Inverse task: During the search for ES the nearest vicinities of the more effective variants based on known ES are screened.

The proposed approach can be represented by the following set [14, 15]:

$$
\{\mathrm{T}, \mathrm{Z}, \mathrm{W}, \mathrm{V}, \mathrm{O}, \mathrm{L}, \mathrm{M}, \mathrm{N}, \mathrm{K}, \mathrm{C}, \mathrm{P}\}
$$

In the realized approach and computer program the following options can be selected in Table 1.

To illustrate this approach two ES have been synthesized and studied.

\section{ADVANCED MORPHOLOGICAL APPROACH FOR THE ADAPTIVE NOISE INSULATION SYSTEM}

Current R\&D efforts to develop quiet aircraft configurations feature, amongst other solutions, engines relocated to the positions above the wing or at the rear fuselage as well as fully or semi fuselage integrated engines. All of these solutions imply higher noise levels in the cabin. Effective insulation technologies are therefore required to reduce cabin noise. The developed methodology was applied using the Inverse Task approach to search for perspective noise insulation systems based on 4S-technology (Steerable Sound Suppression System). 
Table 1 Sequence of tasks

\begin{tabular}{|c|c|c|c|}
\hline No & & Task & Task Definition \\
\hline 1 & $\mathrm{~T}$ & Formulation of the problem & $\begin{array}{l}t_{1} \text { - synthesize and choose the best ES } \\
t_{2} \text { - reverse ES search }\end{array}$ \\
\hline 2 & $\mathrm{Z}$ & Solution level & $\begin{array}{l}z_{1} \text { - choice of the best function } \\
z_{2} \text { - choose of the best structure }\end{array}$ \\
\hline 3 & $\mathrm{~W}$ & Criteria & $\begin{array}{l}\mathrm{w}_{1}-\text { vector criterion } \\
\mathrm{w}_{2}-\text { scalar criterion }\end{array}$ \\
\hline 4 & V & Additional information & $\begin{array}{l}\mathrm{v}_{1}-\text { no } \\
\mathrm{v}_{2}-\text { well-known or existing solutions } \\
\mathrm{v}_{3}-\text { cross-consistency assessment matrix }\end{array}$ \\
\hline 5 & $\mathrm{O}$ & Measurement method & $\mathrm{o}_{1}$ - point scale \\
\hline 6 & $\mathrm{~L}$ & System investigations & $\begin{array}{l}l_{1} \text { - integrated system } \\
l_{2} \text { - the study of the subsystems }\end{array}$ \\
\hline 7 & M & Variants assess & $\begin{array}{l}\mathrm{m}_{1} \text { - variants assessment in general, after the } \\
\text { synthesis of the parts } \\
\mathrm{m}_{2} \text { - evaluation of individual subsystems } \\
\text { before the synthesis }\end{array}$ \\
\hline 8 & $\mathrm{~N}$ & Variants generating & $\begin{array}{l}\mathrm{n}_{1}-\text { loop through all variants } \\
\mathrm{n}_{2} \text { - loop through all variants with choice } \\
\mathrm{n}_{3} \text { - random selection } \\
\mathrm{n}_{4} \text { - random selection with choice }\end{array}$ \\
\hline 9 & $\mathrm{~K}$ & Clustering method & $\begin{array}{l}\mathrm{k}_{1}-\text { Hamming distance } \\
\mathrm{k}_{2}-\mathrm{L} 1 \text {-norm }\end{array}$ \\
\hline 10 & $\mathrm{C}$ & Target function & $\begin{array}{l}\mathrm{c}_{1} \text { - additive } \\
\mathrm{c}_{2} \text { - multiplicative }\end{array}$ \\
\hline 11 & $\mathrm{P}$ & $\begin{array}{l}\text { number of levels of the system } \\
\text { under consideration }\end{array}$ & $\begin{array}{l}\mathrm{p}_{1}-\text { one } \\
\mathrm{p}_{2}-\text { two and more }\end{array}$ \\
\hline
\end{tabular}

The investigations demonstrated the possibility of reducing significantly the cabin noise level by using thin-walled porous materials $[16,17]$. This effect has been achieved by the new 4S-technology due to the creation of deformation zones on the surface and along the thickness of an insulating material as well as the interaction of that material with elastic membranes. A variable level of deformation and, hence, density of this sound 
insulation material enables an adaptation to a desired degree of sound suppression and also to a desired frequency band. This ultimately allows the creation of active and adaptive systems for sound insulation alongside passive ones.

The synthesis process for this problem goes through the following steps.

1. For the problem solving the following set of subtasks is selected from Table 1:

$$
\left\{\mathrm{t}_{2}, \mathrm{z}_{2}, \mathrm{w}_{1}, \mathrm{v}_{2}, \mathrm{o}_{1}, \mathrm{l}_{1}, \mathrm{~m}_{1}, \mathrm{n}_{2}, \mathrm{k}_{1}, \mathrm{c}_{1}, \mathrm{p}_{1}\right\}
$$

2. The morphological matrix is created and reduced to the key characteristics (attributes) shown in Table 2. The total space of the morphological matrix contains 1152 potential variants of engineering solutions.

Table 2 Morphological matrix with possible $4 \mathrm{~S}$ system variants

\begin{tabular}{|c|c|c|c|c|c|}
\hline & $\begin{array}{c}\text { attribute } \\
\text { (descriptors) }\end{array}$ & Option 1 & Option 2 & Option 3 & Option 4 \\
\hline 1 & stress & $\begin{array}{l}\text { increased } \\
\text { pressure }\end{array}$ & $\begin{array}{l}\text { reduced } \\
\text { pressure }\end{array}$ & combined & \\
\hline 2 & source of stress & pneumatic & mechanical & electric & hydraulic \\
\hline 3 & membrane & flexible & hard & & \\
\hline 4 & control & no & controlled & adaptive & \\
\hline \multirow[t]{2}{*}{5} & combination & 1 & 2 & 3 & $\mathrm{n}$ \\
\hline & of volume & & & & \\
\hline 6 & $\begin{array}{l}\text { combination } \\
\text { of layers }\end{array}$ & $\begin{array}{l}\text { Homogeneous } \\
\text { material }\end{array}$ & $\begin{array}{l}\text { Heterogeneous } \\
\text { material }\end{array}$ & & \\
\hline 7 & kind of a material & porous & cellular & & \\
\hline
\end{tabular}

3. The reference variant (green cells in the matrix) consists of the following structure:

$$
\left\{\mathrm{P}_{1}{ }^{2}, \mathrm{P}_{2}{ }^{1}, \mathrm{P}_{3}{ }^{1}, \mathrm{P}_{4}{ }^{1}, \mathrm{P}_{5}{ }^{1}, \mathrm{P}_{6}{ }^{1}, \mathrm{P}_{7}{ }^{1}\right\}
$$

$P_{i}^{n}$ where $i$-subscript is an attribute, $n$ - superscript is a particular option of the $\mathrm{i}$-th attribute.

4. Reference variants are entered into a morphological matrix, and then a set of permuted variants is generated.

5. In the next stage of the variant generation their estimated value (Estimation) is calculated, the initial selection is carried out and an array of rational variants for the subsequent analysis is formed.

6. Henceforth, the clustering of the variants by measuring a predefined level of similarity based on the Hamming distance is carried out. For final analysis 60 generated rational variants, grouped in 8 clusters, were chosen (Fig. 2). 


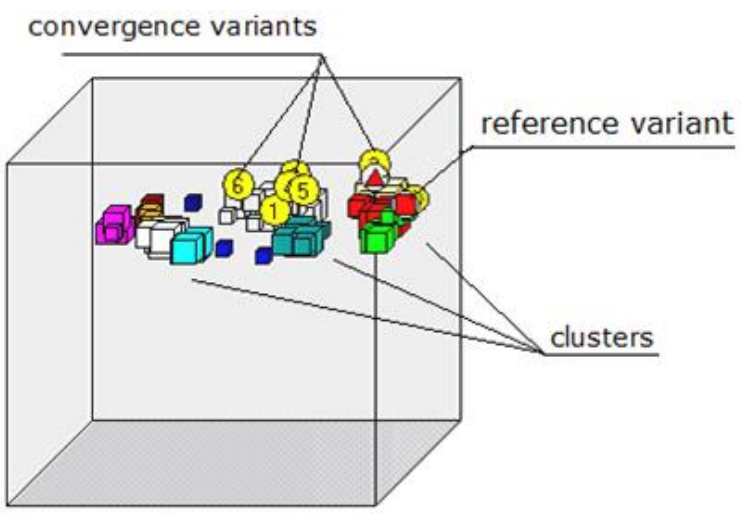

Fig. 2 Clusters and variants in the solutions space

7. After clustering and choosing variants, the final choice set derived from the morphological matrix was analyzed for optimization and experimental investigations (Figs. 3 and 4).

$$
\left\{\mathrm{P}_{1}{ }^{2}, \mathrm{P}_{2}{ }^{1}, \mathrm{P}_{3}{ }^{1}, \mathrm{P}_{4}{ }^{1} \Lambda \mathrm{P}_{4}{ }^{2} \Lambda \mathrm{P}_{4}{ }^{3}, \mathrm{P}_{5}{ }^{1}, \mathrm{P}_{6}{ }^{1} \Lambda \mathrm{P}_{6}{ }^{2}, \mathrm{P}_{7}{ }^{1} \Lambda \mathrm{P}_{7}{ }^{1}\right\}
$$

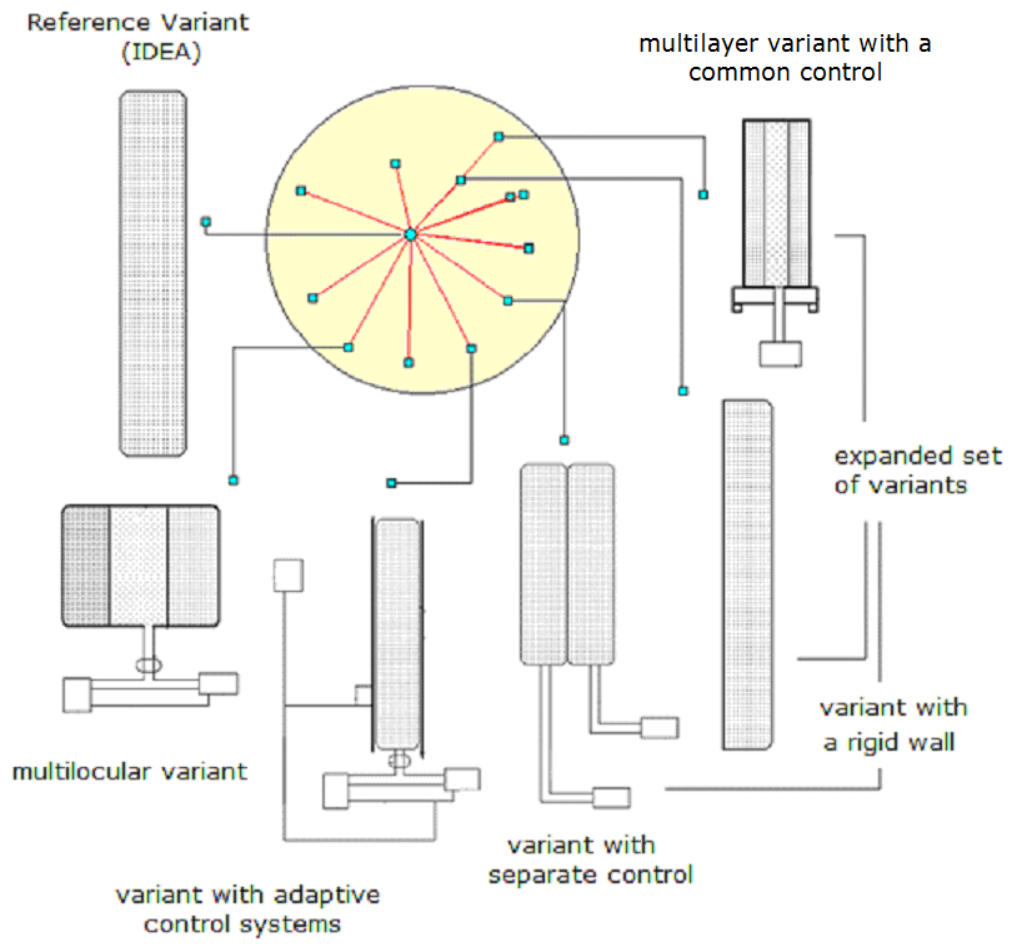

Fig. 3 Expanded set of variants with $4 \mathrm{~S}$ technology 


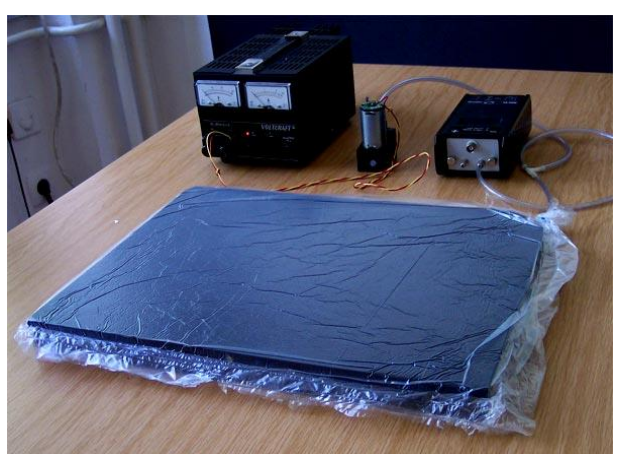

Fig. 4 Sound-insulating experimental panel enclosed in an airproof package, vacuum pump and indicator in the rear

During the experiments the type of materials, the degree of deformation, porosity, rigidity, etc. were varied. The tension in the investigated samples was created mechanically and pneumatically. The tests were carried out in a frequency band from 63 up to $5000 \mathrm{~Hz}$. In the appropriate low-pressure (stress range) the experimental panels exhibit different sound insulation properties. Pressure change is less than $1 \%$ from atmospheric pressure. The average sound insulation achieved was $12 \mathrm{~dB}$ on the basis of the 4 S-effect (Fig. 5).

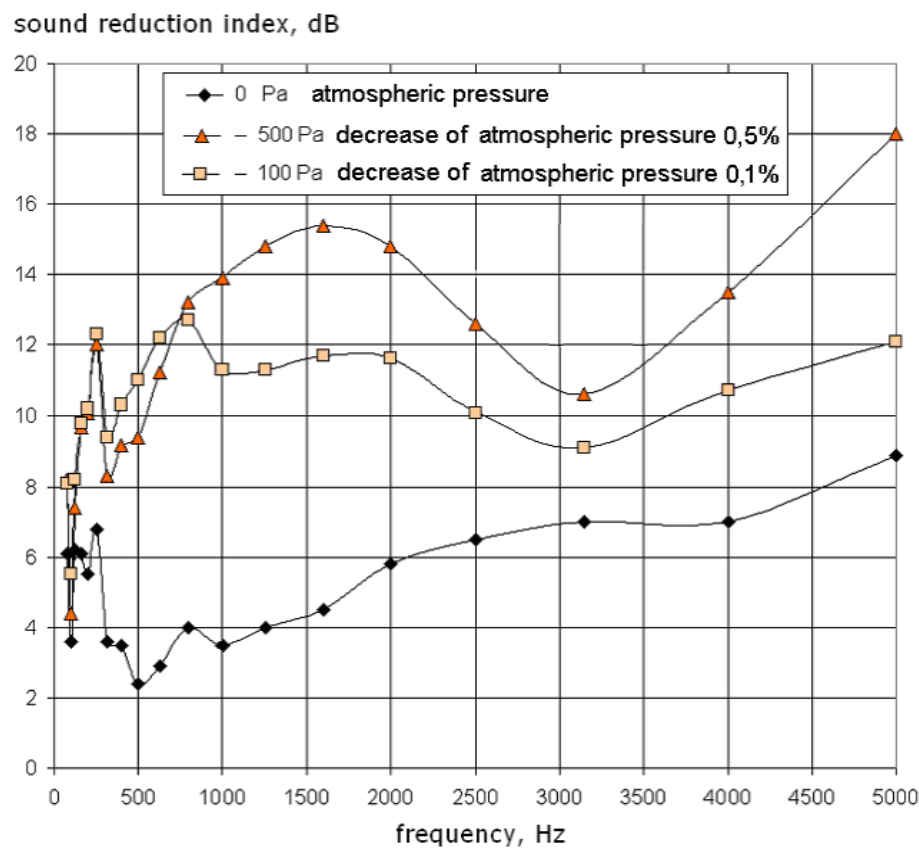

Fig. 5 Sound reduction index of foamed 30-mm polyurethane panel under low-pressure (Decrease from atmospheric pressure less as $1 \%$ ) 


\section{AdVANCED MORPHOLOGICAL APPROACH FOR STRATOSPHERIC UNMANNED AIRCRAFT SYSTEMS}

The number of potential roles for unmanned aircraft systems (UAS) systems is legion, especially in the civil field. The demands defined by the customer lead to the system requirements which determine principally shape, size, performance and costs of the air vehicle, but also of the overall UAS operating system. Some of the more important parameters involved, beginning with the air vehicle, are briefly discussed below [19].

The studied UAS shall have performance potential to fulfill the following mission:

- UAS with civil mission (e.g. observation, research, communication node, etc.)

- Flight altitude: $12-20 \mathrm{~km}$ (above Jetstream)

- Long flight in the stratosphere (as long as possible on station; ideal: $>1$ Week)

- No range requirement - defined position be hold within area of $4 \mathrm{~km}^{2}$

- Max. $10 \mathrm{~m} / \mathrm{s}$ wind during climb - no Jetstream - max. $10 \mathrm{~m} / \mathrm{s}$ wind on position for 4h/day flight time

- Payload $1 \mathrm{~kg}$, constant 50W electric energy consumption.

For the problem solving the following set of subtasks was selected from Table 1:

$$
\left\{\mathrm{t}_{1}, \mathrm{z}_{1}, \mathrm{w}_{1}, \mathrm{v}_{2}, \mathrm{o}_{1}, \mathrm{l}_{1}, \mathrm{~m}_{1}, \mathrm{n}_{2}, \mathrm{k}_{1}, \mathrm{c}_{1}, \mathrm{p}_{1}\right\}
$$

The morphological matrix and the criterion table are given in Tables 3 and 4. The complete morphological matrix contains in total 248,832 potential UAS variants. First, 12,000 variants are generated using random selection. Then 256 best variants identified by experts ( $2 \%$ of the 12,000) are selected for analysis and grouped into 16 clusters (Fig. $5)$. For the clustering a geometric approach based on the compactness hypothesis is used. The solution space also contains 15 reference variants (Fig. 6).

Table 3 Criterion table

\begin{tabular}{lll}
\hline Criteria & Comments \\
\hline 1 UAS System Cost & $\begin{array}{l}\text { Estimated cost of complete system (Ground Support \& UAS) } \\
\text { Cost per mission/flight incl. Cost for fuel/energy, operators, etc. } \\
2 \text { Cost per Mission }\end{array}$ Total Weight/Mission Flight Time & $\begin{array}{l}\text { This is a technical key performance indicator for a long } \\
\text { endurance mission }\end{array}$ \\
4 Emissions & Emissions like $\mathrm{CO}_{2}$, etc. and noise \\
5 Reliability & \\
6 Energy Efficiency & Capability of UAS to reach mission altitude and endure wind \\
7 Speed (Wind and time for climb) & Time of UAS to stay on the predefined position \\
8 Flight duration & $\begin{array}{l}\text { (time for climb/descent excluded) } \\
\text { Safe operation including hazards from fuel, tethers, } \\
\text { electromagnetic waves, etc. }\end{array}$ \\
9 Safety (flight in the stratosphere) &
\end{tabular}


Table 4 Morphological Matrix

\begin{tabular}{|c|c|c|c|c|c|c|}
\hline Category & $\mathrm{P}_{\mathrm{X}}$ & $\begin{array}{c}\text { Attribute } \\
\text { (descriptors) }\end{array}$ & Option $\mathrm{P}_{\mathrm{X}}^{1}$ & Option $\mathrm{P}_{\mathrm{X}}^{2}$ & Option $\mathrm{P}_{\mathrm{X}}^{3}$ & Option $\mathrm{P}_{\mathrm{X}}^{4}$ \\
\hline Lift & 1 & Lift & aerodynamic & Thrust & aerostatic & \\
\hline Thrust & 2 & Thrust & $\begin{array}{l}\text { coupled to lift } \\
\text { generation }\end{array}$ & $\begin{array}{l}\text { independent } \\
\text { from lift } \\
\text { generation }\end{array}$ & & \\
\hline $\begin{array}{l}\text { Energy } \\
\text { Storage }\end{array}$ & 3 & $\begin{array}{c}\text { Internal Energy } \\
\text { storage }\end{array}$ & non & $\begin{array}{l}\text { chemical, } \\
\text { reversible } \\
\text { (e.g. LiPo } \\
\text { battery) }\end{array}$ & $\begin{array}{c}\text { chemical, } \\
\text { irreversible } \\
\text { (e.g. fuel tank) }\end{array}$ & $\begin{array}{l}\text { mechanic } \\
\text { (e.g. } \\
\text { fly-wheel) }\end{array}$ \\
\hline $\begin{array}{l}\text { Energy } \\
\text { supply }\end{array}$ & 4 & $\begin{array}{l}\text { External Energy } \\
\text { Supply }\end{array}$ & non & $\begin{array}{l}\text { continuous } \\
\text { (e.g. solar, } \\
\text { microwave) }\end{array}$ & $\begin{array}{l}\text { interrupted, } \\
\text { discontinuous } \\
\text { (e.g. tank) }\end{array}$ & \\
\hline \multirow[t]{2}{*}{$\begin{array}{l}\text { Power } \\
\text { generation }\end{array}$} & 5 & Engines & electric & $\begin{array}{c}\text { internal } \\
\text { combustion } \\
\text { (e.g. diesel } \\
\text { engine) }\end{array}$ & gas turbine & $\begin{array}{l}\text { reaction } \\
\text { engine, } \\
\text { e.g. rocket } \\
\text { motor }\end{array}$ \\
\hline & 6 & Engines & single engine & twin engines & $\begin{array}{c}\text { more than } 2 \\
\text { engines }\end{array}$ & \\
\hline \multirow[t]{2}{*}{$\begin{array}{l}\text { Flight } \\
\text { control }\end{array}$} & 7 & $\begin{array}{l}\text { Flight height } \\
\text { control }\end{array}$ & $\begin{array}{l}\text { aerodynamic } \\
\text { (e.g. elevators) }\end{array}$ & $\begin{array}{l}\text { changing of } \\
\text { thrust }\end{array}$ & aerostatic & \\
\hline & 8 & $\begin{array}{l}\text { Flight directional } \\
\text { control }\end{array}$ & $\begin{array}{l}\text { aerodynamic } \\
\text { (e.g. rudder) }\end{array}$ & $\begin{array}{c}\text { Thrust } \\
\text { imbalance } \\
\text { (e.g. two } \\
\text { engine }\end{array}$ & & \\
\hline $\begin{array}{l}\text { Geometry } \\
\text { Fuselage }\end{array}$ & 9 & Fuselage & no & one fuselage & twin-boom & \\
\hline \multirow{2}{*}{$\begin{array}{l}\text { Geometric } \\
\text { Characteris } \\
\text { tics Wing }\end{array}$} & 10 & $\begin{array}{l}\text { increasing the } \\
\text { wing area }\end{array}$ & no & Yes & & \\
\hline & 11 & Wing area control & no & $\begin{array}{l}\text { yes, e.g. max. } \\
\text { solar } \\
\text { radiation use }\end{array}$ & & \\
\hline \multirow[t]{2}{*}{$\begin{array}{l}\text { Flight } \\
\text { guidance }\end{array}$} & 12 & Trajectory & constant height & $\begin{array}{c}\text { changing } \\
\text { height }\end{array}$ & & \\
\hline & 13 & Guidance & $\begin{array}{c}\text { remote } \\
\text { controlled }\end{array}$ & Autonomous & & \\
\hline
\end{tabular}



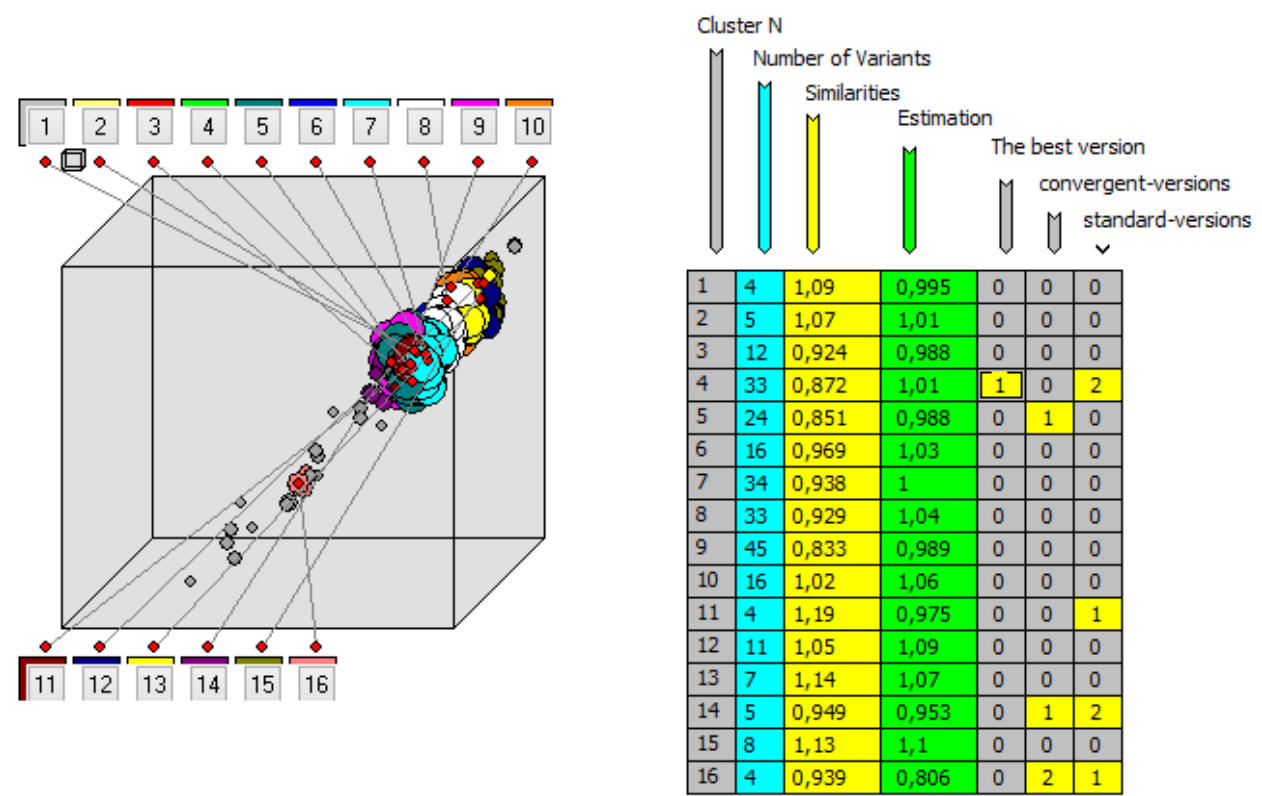

Fig. 5 Solutions space of UAS with 16 Clusters
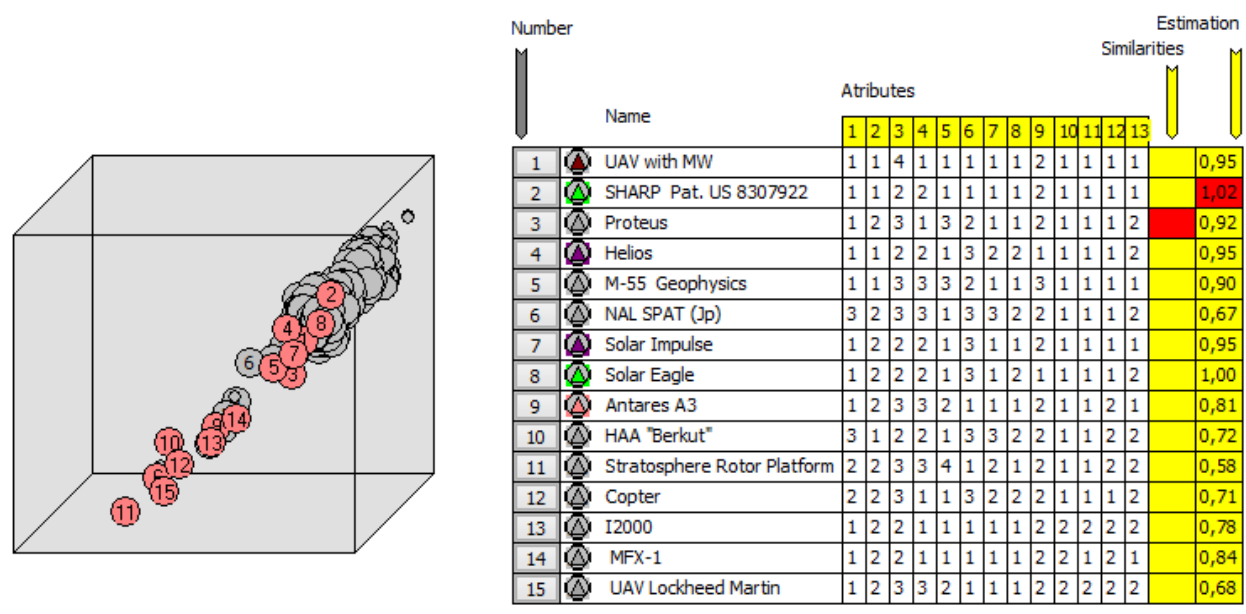

Fig. 6 Solutions space of UAS with 15 reference variants

Based on the cluster analysis and after expert analysis, the following conclusions can be drawn [20]:

1. Many variants have incompatible options or, based on today's knowledge, are impossible to implement (Fig. 5: clusters 7, 8, 13, 15 and 16)

2. Among the reference variants (Fig. 6), the configuration SHARP, Pat.US 8307922, [21] and the configurations SolarEagle, Helios, Solar Impulse have the highest relative value, 
i.e. "Estimation" in Fig. 6 has the highest value. The reference configuration showing the lowest value for the required mission is the Stratosphere Rotor Platform [22]

3. Better Reference Variant No. 32 is in Cluster 4. Improved reference variables are located in cluster 4. Without external energy supply, UAS solutions correspond to the aerodynamic configuration (cluster 4) or helicopter configuration (cluster 5) with power supply by cable.

4. Many generated and selected variants as well as complete clusters have hybrid properties (Table 3: Attributes P1 and P2).

5. Cluster 14 contains aerodynamic electrical UAS with energy storage on board with external power supply with aerodynamic or thrust control.

For further examinations, the following four areas are of interest:

1. Aerodynamic configurations with energy storage on board as well as external power supply and with aerodynamic or thrust vector flight control.

2. Investigations of hybrid UAS.

3. Aerodynamic configurations or helicopter configurations with power supply by cable.

\section{CONCLUSIONS}

The major aim of the presented approach is the expansion of the number of potential variants, their clustering and efficient selection during the solution space synthesis, in order to increase the number of innovative solutions in Engineering Design. In two case studies the technique demonstrates the power of the approach for generating design concepts.

In addition to the above, the proposed approach clarifies and arranges the structuration of the decision task. The validity of decision-making increased while the multitude of variants among which the selection is carried out is broadened. This enables quality improvement of the developed engineering systems.

\section{REFERENCES}

1. Hubka, V., Eder, W.E., 1998, Theory of Technical Systems: A Total Concept Theory for Engineering Design, New York:Springer-Verlag, $278 \mathrm{p}$.

2. Milčić, D., Miltenović, V., 1999, Application of artificial intelligence methods in gear transmitters conceptual design, Facta Universitatis-Series Mechanical Engineering, 1(6), pp.721-734.

3. Polovinkin, A., 1991, Design theory of new engineering solutions: technology patterns and their applications. Edn. Informelectro, $104 \mathrm{p}$.

4. Mishin, V., Osin, M., 1978, Introduction to Aircrafts Design, Moscow: Edn. Mashinostroenie, 128 p.

5. Zwicky, F., 1966, Entdecken, Erfinden, Forschen im morphologischen Weltbild, Droemer/Knaur, München, Zürich, $206 \mathrm{p}$.

6. Ritchey, T., 2006, Problem Structuring using Computer-Aided Morphological Analysis, Journal of the Operational Research Society, 57(7), pp. 1-12.

7. Pahl, G., Beitz, W., 1996, Engineering design: a systematic approach, 2nd edn. Springer, London, 617 p.

8. Matthews, P., 2011, Challenges to Bayesian decision support using morphological matrices for design: empirical evidence, Research in Engineering Design, 22(1), pp. 29-42.

9. Grote, K.H., Antonsson, E. (Eds.), 2011, Springer Handbook of Mechanical Engineering, Springer, 1520 p. 
10. Fargnoli, M., Troisi, R., Rovida, E., 2006, The morphological Matrix: Tool for the Development of innovative Design Solutions, 4th International Conference on Axiomatic design, ICAD, June 13-16, 2006, Florence, Italy, pp. 1-7.

11. Levin, M.S., 2015, Modular System Design and Evaluation, Springer, $413 \mathrm{p}$

12. VDI Standard: VDI 2221, 1993, Systematic approach to the development and design of technical systems and products, Beuth Verlag.

13. VDI Standard: VDI 2222,1997 , Part 1. Methodic development of solution principles. Beuth Verlag.

14. Andreychikov, A., Andreichikova, O., 2014, System analysis and synthesis of strategic decisions in Innovation: Conceptual design of innovative systems, Moscow, Edn. URSS, $424 \mathrm{p}$.

15. Rakov, D., 1996, Morphological Synthesis Method of the Search for Promising Technical Systems, IEEE Aerospace and Electronic Systems magazine, 12, pp.3-8.

16. Rakov, D., Thorbeck, J., 2008, Ein Beitrag zur Beeinflussung des Schalldämmungsverhaltens von akustischen Dämmelementen, Lärmbekämpfung - Zeitschrift für Akustik, Schallschutz und Schwingungstechnik, 1/2008, pp. 41-43.

17. Rakov, D., Thorbeck, J., Pecheykina, M., 2018, Design and Modeling of Adaptive Noise Suppression Systems with Morphological Approach. In: Hu, Z., Petoukhov, S., He, M. (Eds), Advances in Artificial Systems for Medicine and Education - AIMEE 2017, Advances in Intelligent Systems and Computing, vol. 658. Springer, Cham, pp. 266-272.

18. Rakov, D., Timoshina, A., 2010, Structure synthesis of prospective technical systems, IEEE Aerospace and Electronic Systems Magazine, 25(2), pp. 4-10.

19. Austin, R., 2010, Unmanned Aircraft Systems: UAVS Design, Development and Deployment, Wiley, $372 \mathrm{p}$

20. Bardenhagen, A., Gavrilina, L.V., Klimenko, B.M., Pecheykina, M.A., Rakov, D.L., Statnikov, I.N., 2017, A comprehensive approach to the structural synthesis and evaluation of engineering solutions in the design of transportation and technological systems, Journal of Machinery Manufacture and Reliability, 46(5), pp. 453-462.

21. DeLaurier, J., Gagnon, B., Wong, J., Williams, R., Hayball, C.,1985, Research on the technology of an airplane concept for a Stationary High Altitude Relay Platform (SHARP), $32^{\text {nd }}$ Annual General Meeting of the Canadian Aeronautics and Space Institute, Montreal, May 27, pp. 5-22.

22. Wilfred, P.S., Petrides, T., 1961, Supersonic rotary wing platform, Patent USA 3116040, Date of priority - 26. June 1961. 